\title{
PERAN DIPLOMASI KELAUTAN DAN PERIKANAN SEBAGAI BAGIAN UPAYA MENANGGULANGI PERIKANAN ILEGAL DI INDONESIA
}

\author{
The Role of Marine and Fisheries Diplomacy as a Part of \\ Eradicate IIlegal Fishing in Indonesia
}

\author{
Bayu Vita Indah Yanti, Sonny Koeshendrajana dan Freshty Yulia Arthatiani \\ Balai Besar Penelitian Sosial Ekonomi Kelautan dan Perikanan \\ JI. KS. Tubun Petamburan VI Jakarta 10260 \\ Telp. (021) 53650162, Fax. (021)53650159 \\ Email: bviy1979@gmail.com \\ Diterima 27 Maret 2013 - Disetujui 31 Mei 2013
}

\begin{abstract}
ABSTRAK
Permasalahan perikanan ilegal di Indonesia merupakan salah satu bentuk kejahatan transnasional yang terjadi di Indonesia. Berbagai upaya dilakukan untuk menanggulangi permasalahan perikanan ilegal di Indonesia untuk menekan kerugian bagi Indonesia. Salah satu upaya yang dilakukan untuk menangani permasalahan perikanan ilegal ini dengan melakukan diplomasi antarnegara khususnya di bidang kelautan dan perikanan. Bagaimana peran diplomasi kelautan dan perikanan Indonesia untuk menanggulangi perikanan ilegal di Indonesia merupakan salah satu permasalahan yang dikaji dalam kajian aspek hukum dalam memerangi kegiatan IIlegal Unreported Unregulated Fishing (IUUF). Metode penelitian yang digunakan merupakan penelitian hukum empiris karena dilakukan berdasarkan pada kondisi faktual permasalahan yang terjadi hingga saat ini. Analisis data dilakukan secara kualitatif deskriptif. Hasil penelitian menemukan bahwa peran diplomasi bidang kelautan dan perikanan amat penting dan dapat meningkatkan posisi tawar Indonesia dalam melakukan negosiasi antarnegara di bidang kelautan dan perikanan, meski saat ini hal tersebut masih dianggap belum maksimal dilaksanakan. Jika diplomasi dapat berperan secara maksimal, maka negara lain terutama negara-negara asal pelaku IUUF di Indonesia dapat melakukan upaya pencegahan agar warganegaranya tidak melakukan kegiatan perikanan ilegal di Indonesia. Diplomasi ini penting dilakukan oleh kementerian terkait (Kementerian Kelautan dan Perikanan (KKP), Kementerian Luar Negeri (Kemenlu), serta didukung pula oleh semua pihak yang mewakili kepentingan Indonesia di mancanegara.
\end{abstract}

Kata Kunci: peran diplomasi, bidang kelautan dan perikanan, penanganan perikanan ilegal

\begin{abstract}
Problem of illegal fishing in Indonesia is one of transnational crime that occurred in Indonesia. Various efforts were made to address the problem of illegal fishing in Indonesia in order to reduce losses. One of the efforts made to address the problem of illegal was through fishing diplomacy between related countries, particularly in marine affairs and fisheries field. How the role of marine and fisheries Indonesian diplomacy to tackle illegal fishing in Indonesia is one of the issues to examined in the study of the legal aspects against Illegal Unreported Unregulated Fishing activities (IUUF). Method of an empirical legal research because it is based on factual conditions of the problems on current situation. Results of the research showed that the role of diplomacy in marine and fisheries sector is very important and can improve Indonesia's bargaining position in negotiations between countries in marine affairs and fisheries field, although it is not maximized yet on implementation. Neighboring countries Indonesia could prevent IUUF when they maximized diplomacy and achieve agreement among them. There for, diplomacy is important to be undertaken by the relevant ministries, i.e., (Ministry of Maritime Affairs and Fisheries (MMAF), the Ministry of Foreign Affairs (Foreign Ministry)), and supported by all parties that represent the interests of Indonesia in foreign countries.
\end{abstract}

Keywords: the role of diplomacy, marine affairs and fisheries, illegal fishing handling 


\section{PENDAHULUAN}

Jika melihat dari sejarah, Indonesia merupakan negara yang dengan sikap berani dan elegan telah memastikan kedaulatannya sebagai negara kepulauan terbesar di dunia melalui Deklarasi Juanda tanggal 13 Desember 1957. Deklarasi ini juga secara kuat mendorong perdebatan dan kesepakatan baru dalam United Nations Convention on The Law of the Sea (UNCLOS) sehingga memungkinkan definisi negara kepulauan (achipelagic state) disuarakan dengan jelas dan dirumuskan tahun 1982 (UNCLOS 1982). Meskipun UNCLOS 1982 sebagai kerangka pengaturan utama dan mendapat pengakuan mayoritas bangsa-bangsa secara internasional dalam pengelolaan laut global saat ini, tidak sepenuhnya tegas mengatur perlindungan serius terhadap keanekaragaman hayati diluar wilayah yurisdiksi nasional (perairan internasional).

Jika diperhatikan lebih lanjut, UNCLOS 1982 ternyata lebih jelas memberikan ruang eksploitasi sumber daya laut, termasuk sumber daya perikanan dunia yang saat ini tengah krisis akibat penangkapan ikan berlebih (overfishing). Kondisi keberadaan "governance gaps" pada UNCLOS 1982 merupakan alasan strategis dan utama bagi Indonesia untuk memainkan peran positif agar semua pemimpin bangsa-bangsa dapat mengedepankan kebijakan pentingnya pengelolaan lestari dan berkelanjutan sumber daya kelautan melalui pendekatan ekosistem untuk memastikan keseimbangan lingkungan, pengentasan kemiskinan dan ketahanan pangan secara berkelanjutan. Kegiatan World Oceans Conference (WOC) pada tahun 2009 yang telah melahirkan Manado Oceans Declaration (MOD) serta kesepakatan 6 (enam) negara (Filipina, Malaysia, Kepulauan Solomon, Fiji, Papua Nugini, dan Indonesia) yang dipimpin oleh Indonesia terkait penetapan rencana aksi dan titik tolak Coral Triangle Initiative (CTI). Hal ini merupakan salah satu wujud kepemimpinan, komitmen dan peran nyata Indonesia yang patut diapresiasi.

Meskipun jika dilihat dari sisi lainnya, Indonesia memiliki permasalahan terkait maraknya kegiatan perikanan ilegal yang dilakukan oleh warga negara lain di wilayah perairan Indonesia. Hal ini merupakan permasalahan yang perlu ditangani oleh pemerintah Indonesia. Salah satu upaya penanganan perikanan ilegal di Indonesia adalah dengan meningkatkan peran diplomasi bidang kelautan dan perikanan yang dilakukan antarnegara, mengingat perikanan ilegal merupakan salah satu bentuk kejahatan transnasional sehingga upaya terbaik untuk penanganannya melalui kerjasama antarnegara. Jika permasalahan perikanan ilegal tidak ditangani secara komprehensif, maka tidak hanya mengancam keberlanjutan sumber daya kelautan melainkan juga mengancam kedaulatan wilayah perairan Indonesia secara tidak langsung, karena perikanan ilegal merupakan salah satu bentuk ancaman nirmiliter bagi keamanan wilayah perairan Indonesia saat ini.

Berdasarkan pada uraian tersebut, makalah ini akan membahas permasalahan bagaimana peran diplomasi kelautan dan perikanan Indonesia untuk menangani perikanan ilegal di Indonesia. Permasalahan ini penting untuk dibahas karena kegiatan perikanan ilegal merupakan kejahatan transnasional atau merupakan kejahatan dengan pelaku antarnegara, seperti halnya kasus kejahatan human trafficking antarnegara.

\section{METODOLOGI}

\section{Dasar Pemikiran}

Berbagai macam bentuk kejahatan lintas negara terjadi di Indonesia, salah satu diantaranya adalah kegiatan perikanan ilegal. Kegiatan perikanan ilegal dikatakan sebagai kejahatan transnasional, karena dilakukan oleh pelaku antarnegara dengan tempat kejahatan yang dilakukan juga antar negara, dan membawa dampak kerugian bagi negara tempat dilakukannya kejahatan tersebut. Berbagai macam cara dilakukan oleh pemerintah Indonesia untuk mengatasi kegiatan kejahatan transnasional tersebut. Salah satu cara yang dilakukan untuk menangani permasalahan perikanan ilegal adalah melalui diplomasi internasional di bidang kelautan dan perikanan.

Diplomasi bukan merupakan hal baru bagi hubungan antarnegara, karena diplomasi merupakan salah satu cara yang dilakukan untuk membela kepentingan negara di dunia internasional. Jika diplomasi dapat dilakukan secara maksimal untuk menekan kegiatan perikanan ilegal di Indonesia, diharapkan dimasa mendatang keberhasilan Indonesia menekan kegiatan kejahatan antarnegara tersebut dapat memberikan kontribusi penting bagi peran Indonesia dalam tata kelola sumber daya kelautan dan perikanan global (Gambar 1). 


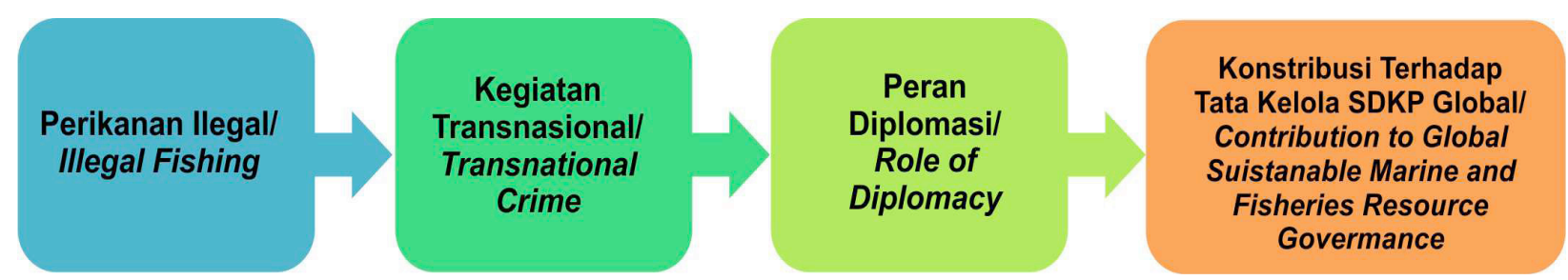

Gambar 1. Kerangka Pemikiran

Flgure 1. Research Framework

\section{Teknik Pengumpulan Data dan Metode Analisis Data}

Teknik pengumpulan data dilakukan dengan studi kepustakaan menggunakan bahan literatur terkait dengan pembahasan permasalahan dan juga dengan melakukan Diskusi Kelompok Terfokus (Focus Group Discussion (FGD)) yang dihadiri oleh narasumber terkait penanganan perikanan ilegal di Indonesia.

Data yang telah diperoleh kemudian dianalisis dengan menggunakan pendekatan dalam analisis kebijaksanaan. Penggunaan analisis kebijaksanaan untuk menganalisis data dan informasi yang diperoleh ditujukan untuk menghasilkan kebijaksanaan yang dapat dimanfaatkan di tingkat politik untuk memecahkan permasalahan kebijaksanaan (Dunn, 2001).

\section{Validitas dan Realibilitas}

Validitas menurut Kamus Besar Bahasa Indonesia, merupakan informasi sejauhmana tingkat kebenaran suatu fakta atau informasi. Validitas data dan informasi yang diperoleh dalam penelitian ini dilihat berdasarkan Content validity dan Internal validity. Content validity adalah sejauhmana skala pengukuran memberi cakupan yang memadai dari pertanyaan-pertanyaan yang bersifat investigatif (Cooper dan Schinder dalam Wahyuni, 2011). Content validity pada penelitian ini dilakukan melalui pemaparan hasil temuan penelitian pada para pemangku kepentingan terkait untuk selanjutnya mendapatkan umpan balik (feedback) dari mereka. Internal validity adalah perkiraan kebenaran kesimpulan tentang sebab akibat atau hubungan kausal (Trochim dan Donenelly dalam Wahyuni, 2011). Internal validity dimaksudkan untuk mendapatkan data dan informasi yang relevan dilakukan dengan mengumpulkan data dan informasi yang relevan dari narasumber terkait dengan permasalahan yang dibahas.
Reliability merupakan derajat konsistensi untuk kategori, meskipun berbeda pengamat atau pengamat yang sama untuk berbeda waktu. Reliability diperlihatkan untuk validasi dengan melakukan inter-rate untuk mendapatkan input dan feedback dari para ahli untuk menyempurnakan hasil penelitian.

Content analysis, internal validity, dan reliability dilakukan bersamaan pada saat penyampaian hasil sementara penelitian ini dalam FGD dan untuk mendapatkan input dan feedback dari narasumber terkait.

\section{PERIKANAN ILEGAL SEBAGAI KEJAHATAN TRANSNASIONAL}

Resolusi Perserikatan Bangsa-Bangsa (PBB) Nomor 55/25 tanggal 15 November 2000 tentang United Nations Convention Againts Transnasional Organized Crime (UNCATOC), dinyatakan bahwa kejahatan transnasional merupakan suatu kejahatan terorganisir antarnegara, tidak stagnan, tetapi merupakan hasil industri yang selalu berubah, beradaptasi dengan pasar dan menciptakan bentuk-bentuk baru kejahatan. Bentuk kejahatan ini melampaui budaya, sosial, bahasa, batas geografis dan tidak mengenal batas atau aturan. Bentuk-bentuk kejahatan ini antara lain perdagangan manusia, penyelundupan, perompakan, pencucian uang, maupun kegiatan perikanan ilegal yang dilakukan antarnegara.

Suatu kejahatan dapat diklasifikasikan menjadi "kejahatan transnasional", jika kejahatan tersebut: dilakukan di lebih dari satu negara, kemudian persiapan, perencanaan, pengarahan dan pengawasan dilakukan di negara lain, dengan melibatkan organisasi kriminal dimana kejahatan dilakukan di lebih dari satu negara, dan berdampak serius pada negara lain (Tulip et al., 2009). Kejahatan transnasional merupakan kejahatan 
terorganisir antarnegara, bersifat dinamis merupakan hasil industri yang selalu berubah, beradaptasi dengan pasar dan menciptakan bentuk-bentuk baru kejahatan. Upaya untuk menangani kejahatan transnasional ini tidak dapat dilakukan hanya oleh satu negara tertentu tempat dilakukannya tindak kejahatan, melainkan memerlukan kerjasama antarnegara. Kerjasama antarnegara perlu dilakukan karena kejahatan transnasional tersebut: dilakukan di lebih dari satu negara, kemudian persiapan, perencanaan, pengarahan dan pengawasan dilakukan di negara lain, dengan melibatkan organisasi kriminal dimana kejahatan dilakukan di lebih dari satu negara, dan berdampak serius pada negara lain. Untuk itulah, perikanan ilegal sebagai salah satu bentuk dari kejahatan transnasional, dalam penanganannya memerlukan kerjasama antarnegara, dan itu berarti memerlukan dilakukannya diplomasi antarnegara.

\section{DIPLOMASI DAN PENANGGULANGAN PERIKANAN ILEGAL}

Advanced Oxford Dictionary 2003 memberi konotasi pengertian dari diplomasi sebagai "manajemen hubungan internasional melalui negosiasi, yang diselaraskan dan diatur oleh duta besar dan para wakil; bisnis atau seni para diplomat dari suatu negara. Jika melihat pengertian diplomasi menurut kamus besar bahasa Indonesia, maka diplomasi menyangkut 4 (empat) hal berikut:

1. urusan atau penyelenggaraan perhubungan resmi antara negara dengan negara;

2. urusan kepentingan sebuah negara dengan perantaraan wakil-wakilnya di negeri lain;

3. pengetahuan dan kecakapan dalam hal perhubungan antara negara dengan negara; dan

4. kecakapan menggunakan kata-kata pilihan yang tepat bagi keuntungan pihak yg bersangkutan (dalam perundingan, menjawab pertanyaan, mengemukakan pendapat, dsb).

Selain pengertian diplomasi tersebut di atas, terdapat pula pendapat pakar hubungan internasional, seperti menurut KM Panikkar dalam bukunya The Principles and Practice of Diplomacy (1956) menyatakan bahwa diplomasi dalam hubungannya dengan politik internasional, adalah seni mengedepankan kepentingan suatu negara dalam hubungannya dengan negara lain; dan menurut pemikiran Satow dalam buku Satow's Diplomatic Practice (2009) dinyatakan bahwa diplomasi merupakan penerapan kecerdasan dan kebijaksanaan untuk pelaksanaan hubungan resmi antarpemerintah negara merdeka, juga untuk memperluas hubungan mereka dengan wilayah territorial, dan antara pemerintah dengan internasional kelembagaan, atau, lebih singkat, pelaksanaan bisnis antarnegara-negara dengan cara-cara damai.

Berdasarkan pada uraian tersebut, dihubungkan dengan pembahasan permasalahan dalam tulisan ini, diplomasi merupakan kegiatan yang dilakukan oleh pemerintah suatu negara sebagai bagian dari politik internasional yang dengan cara-cara damai melalui penerapan kecerdasan dan kebijaksanaan dalam pelaksanaan hubungan resmi antarnegara ataupun antara pemerintah dengan internasional kelembagaan, dengan tujuan untuk mengedepankan kepentingan negara di dunia internasional.

Pendapat Prof. Etty R. Agoes, pakar hukum laut internasional Fakultas Hukum Universitas Padjadjaran Bandung, pada "Focus Group Discussion Kajian Aspek Hukum Dalam Rangka Memerangi IUU Fishing di Indonesia di Jakarta, 10 Desember 2012", terkait dengan penanganan atau penanggulangan IUU Fishing yang merupakan suatu bentuk kejahatan internasional antarnegara (transnasional), menyatakan bahwa salah satu langkah yang perlu dilakukan oleh Kementerian Kelautan dan Perikanan (KKP) adalah melakukan diplomasi terkait rencana aksi terkait isu dan permasalahan perikanan ilegal. Langkah diplomasi tersebut, dilaksanakan KKP dengan tidak harus hanya tergantung pada peran diplomasi yang dilakukan oleh Kementerian Luar Negeri, langkah ini dapat dilaksanakan oleh struktur organisasi KKP itu sendiri, yang utama dalam hal ini adalah Pusat Analisis Kerja Sama Internasional dan Antarlembaga (PUSKITA).

Kebijakan diplomasi luar negeri Indonesia secara nasional untuk pemantapan politik luar negeri dan peningkatan kerjasama internasional adalah dengan meningkatkan peran dan diplomasi Indonesia dalam penanganan isu multilateral $^{1}$. Pelaksanaan kebijakan tersebut dilakukan dengan menerapkan strategi antara lain dengan: meningkatkan partisipasi dan inisiatif Indonesia dalam forum-forum multilateral termasuk mengupayakan agar Indonesia menjadi tuan rumah 
pertemuan multilateral; dan mengidentifikasi dan mengkaji secara kritis, untuk kepentingan efisiensi, partisipasi Indonesia pada organisasi kerjasama multilateral, dengan melihat manfaat langsung bagi kepentingan nasional.

Pusat Analisis Kerjasama Internasional dan Antarlembaga (PUSKITA) merupakan vocal point yang diberikan mandat untuk mewujudkan visi dan misi KKP dan juga kebijakan nasional terkait politik luar negeri dan peningkatan kerjasama internasional. PUSKITA mempunyai peranan penting dalam membangun dan memantapkan posisi Indonesia dalam kerjasama internasional bidang kelautan dan perikanan². Salah satu indikator keberhasilan kerjasama internasional tersebut adalah dengan meningkatnya persentase keberhasilan implementasi kerjasama internasional bidang kelautan dan perikanan. Peran penting yang dijalankan oleh PUSKITA tersebut hingga saat ini masih dirasakan kurang optimal. Informasi tersebut mengemuka pada saat pelaksanaan "FGD Kajian Aspek Hukum Dalam Rangka Memerangi IUU Fishing di Indonesia", terkait dengan penanganan atau penanggulangan IUU Fishing antarnegara. Diplomasi dalam konteks ini merupakan salah satu cara Indonesia untuk melakukan negosiasi dengan negara lain demi mengurus kepentingan Indonesia terkait dengan pembangunan kelautan dan perikanan di Indonesia.

Kebijakan luar negeri yang dianut Indonesia berdasarkan prinsip bebas dan aktif dengan mengacu pada kepentingan nasional. Bebas dalam arti Indonesia bebas untuk menentukan sikap dan kebijaksanaan terhadap permasalahan intemasional dan tidak mengikatkan diri secara apriori pada satu kekuatan dunia, dan aktif dalam arti Indonesia secara aktif memberikan sumbangan, baik dalam bentuk pemikiran maupun partisipasi aktif dalam menyelesaikan konflik, sengketa dan permasalahan dunia lainnya. Kebijakan politik luar negeri Indonesia tersebut merupakan upaya untuk mendukung terwujudnya tujuan nasional sebagaimana tercantum di dalam Pembukaan Undang-Undang Dasar 1945, alinea 4: “....ikut melaksanakan ketertiban dunia yang berdasarkan kemerdekaan, perdamaian abadi dan keadilan sosial..... Pernyataan Linggarwati
Hakim, Dirjen Hukum dan Perjanjian Internasional, Kemenlu, pada saat Forum Koordinasi Hukum dan Organisasi KKP, diplomasi yang dilakukan oleh Indonesia merupakan diplomasi total. "Diplomasi total dalam hal ini merupakan diplomasi yang melibatkan semua komponen bangsa dalam suatu sinergi dan memandang substansi permasalahan secara integratif." Berdasarkan pada pernyataan tersebut, KKP sebagai salah satu komponen bangsa, juga dapat melakukan fungsi diplomasi sebagai salah satu cara untuk menjalankan visi dan misi KKP. Pertimbangan lain terkait pentingnya upaya peningkatan peran diplomasi kelautan dan perikanan Indonesia disebabkan karena Indonesia sebagai negara yang memiliki luas wilayah perairan lebih dari $75 \%$ memiliki kepentingan besar untuk memperkuat diplomasi bidang kelautan dan perikanan terutama terkait dengan isu tata kelola kelautan global.

Permasalahan perikanan ilegal di Indonesia yang dianggap mengancam perekonomian maupun keamanan wilayah maupun sumber daya merupakan kegiatan yang dilakukan oleh warga negara asing (pelaku asing). Penanganan pada para pelaku asing ini menyebabkan Indonesia dipandang perlu dan penting untuk melakukan komunikasi dengan negara lain. Namun pada kenyataannya, kemampuan diplomasi dari KKP masih dianggap kurang optimal dan memerlukan upaya peningkatan kemampuan diplomasi, karena KKP merupakan kementerian yang diberi mandat khusus untuk menangani permasalahan bidang kelautan dan perikanan. Salah satu contoh bentuk penyelesaian permasalahan bidang kelautan dan perikanan antarnegara dilakukan melalui jalur diplomasi, seperti yang dilakukan oleh pemerintah Indonesia dengan Malaysia melalui penandatanganan nota kesepahaman di awal tahun 2012.

Diplomasi antarnegara dilakukan sebagai salah satu strategi penanganan perikanan ilegal yang merupakan salah satu bentuk kejahatan transnasional di Indonesia. Diplomasi yang perlu dilakukan dengan memberikan data dan informasi terkait dengan bentuk-bentuk pelanggaran perikanan ilegal yang telah dilakukan oleh warga negara asing kepada negara-negara asal mereka, dengan tujuan:

\footnotetext{
${ }^{1}$ Keputusan Direktur Jenderal Multilateral Kementerian Luar Negeri (Kemenlu), Nomor 00148/PL/II/2010/46/06 tentang Penetapan Rencana Strategis Direktorat Jenderal Multilateral Tahun 2010-2014.

${ }^{2}$ Mengacu pada materi yang terdapat di http://puskita.kkp.go.id/i2/index.php/kerjasama/kerjasama-antarlembaga/23-kerjasama
} 
Terwujudnya compliance terhadap peraturanperaturan yang diberlakukan Indonesia dalam upaya penanggulangan perikanan ilegal pada pelaku-pelaku dari negara partner bilateral maupun multilateral, dan;

Terwujudnya kesepahaman dalam penanganan perikanan ilegal. Sebagai contoh, pada saat terjadi pelanggaran yang dilakukan oleh nelayan Indonesia di negara tersebut, pemerintah dapat menjadikan data pelanggaran negara tersebut sebagai alat bantu dukung pembelaan bagi nelayan Indonesia; sebaliknya pemerintah Indonesia dapat memberikan alasan bahwa nelayan Indonesia melakukan pelanggaran karena sumber daya ikan di Indonesia juga telah dicuri oleh nelayan dari negara tersebut.

KKP selaku kementerian teknis bidang kelautan dan perikanan, dalam melakukan upaya diplomasi bidang kelautan dan perikanan untuk penanganan perikanan ilegal, memerlukan kerjasama antarinstitusi pemerintah. KKP perlu bekerjasama dan berkoordinasi dengan instansi terkait lainnya, seperti dengan institusi yang diamanatkan undang-undang untuk mengamankan kedaulatan negara di wilayah perairan, dan untuk melakukan diplomasi antarnegara. Instansiinstansi ini diantaranya adalah Kementerian Luar Negeri (Kemenlu), Kementerian Hukum dan HAM (Kemenkumham), dan Kementerian Pertahanan (Kemhan).

Kerjasama dengan Kemenlu penting dilakukan karena tugas yang diamanatkan oleh Presiden pada kementerian ini adalah membidangi permasalahan yang terkait dengan hubungan antarnegara. Meskipun KKP juga tidak dapat tergantung sepenuhnya pada kementerian ini, karena tidak semua diplomat menguasai secara substansial permasalahan terkait bidang kelautan dan perikanan.

Kerjasama dengan Kemenkumham, dalam hal penanganan para pelaku perikanan ilegal diperlukan, terkait dengan penanganan para pelaku yang merupakan warga negara asing WNA). Berdasarkan tugas pokok dan fungsi penanganan terhadap WNA merupakan tugas keimigrasian. Direktorat Jenderal Imigrasi merupakan institusi dibawah Kemenkumham yang memiliki tugas untuk melakukan hubungan diplomatik antarnegara terkait dengan masalah pendeportasian WNA.

Kerjasama dengan Kemhan juga perlu dilakukan oleh KKP, mengingat perikanan ilegal merupakan kejahatan antarnegara dan memiliki potensi ancaman bagi pertahanan dan keamanan Indonesia. Peran diplomasi bidang keamanan kelautan merupakan salah satu peran yang dimiliki oleh Tentara Nasional Indonesia Angkatan Laut (TNI AL), dan Kemhan dapat membantu KKP untuk memperkuat peran diplomasi KKP tersebut melalui pelaksanaan peran TNI AL dan juga melalui peran bidang strategi pertahanan di Kemhan. Hal ini mungkin dilakukan, karena perikanan ilegal jika dikaji lebih mendalam merupakan salah satu bentuk ancaman nirmiliter bagi pertahanan dan keamanan wilayah Indonesia.

Upaya-upaya yang dilakukan oleh KKP dalam rangka penanganan kegiatan perikanan ilegal di Indonesia, baik yang dilakukan antarinstansi di dalam negeri maupun yang dilakukan antarnegara melalui kegiatan diplomasi antarnegara, merupakan bentuk upaya pemerintah Indonesia untuk berkontribusi pada tata kelola sumber daya kelautan dan perikanan ilegal yang berkelanjutan.

\section{PENUTUP}

Diplomasi merupakan salah satu cara damai yang ditempuh antarnegara dalam membela kepentingan negara di tingkat internasional. Salah satu cara yang ditempuh untuk menangani kegiatan perikanan ilegal yang dilakukan oleh warga negara asing di wilayah perairan Indonesia. Meskipun hingga saat ini masih dirasakan belum maksimal pelaksanaan peran diplomasi tersebut untuk membela kepentingan bidang kelautan dan perikanan Indonesia, mengingat kompleksitas keterkaitan kegiatan perikanan ilegal tersebut dengan bidang lainnya.

Peningkatan kemampuan diplomasi KKP merupakan kebutuhan mutlak, kebutuhan ini dapat dipenuhi dengan cara memberikan bekal dan memperkuat penyediaan data dan informasi yang akan disampaikan oleh semua pejabat KKP yang akan melakukan tugas mewakili (delegasi) negara Indonesia dalam kancah pertemuan internasional. Selanjutnya, diplomasi perlu diarahkan untuk mewujudkan terbentuknya kemauan untuk sharing data dan informasi antar negara yang terkait. Jika para perwakilan KKP memiliki data dan informasi yang komprehensif dan up to date terkait bidang kelautan dan perikanan, terutama dengan seriusnya penanganan perikanan ilegal di Indonesia, pada saat melakukan kegiatan pertemuan dengan negara lain, dapat menjadi salah satu bentuk peningkatan posisi tawar Indonesia pada saat 
Indonesia melakukan negosiasi dengan negara lain yang telah merugikan negara Indonesia. Peningkatan posisi tawar Indonesia dikarenakan sikap Indonesia peduli untuk menangani perikanan ilegal, akan membuat negara lain yang berminat untuk melakukan eksploitasi sumber daya ikan di Indonesia, dengan melakukan hal tersebut secara legal dengan mematuhi aturan-aturan yang telah ditetapkan oleh pemerintah Indonesia. Implikasi lain yang dapat terjadi jika diplomasi bidang kelautan dan perikanan. Peran PUSKITA dilakukan berdasarkan pada tugas pokok dan fungsi yang ditetapkan. Namun pada saat pelaksanaannya PUSKITA tetap harus mendapatkan dukungan dalam pelaksanaan tugas dan fungsinya dari komponen KKP lainnya.

Jika kebijakan diplomasi tersebut dilakukan, maka diperkirakan dapat memberikan implikasi terkait peningkatan kemampuan diplomasi KKP, akan mempermudah mewujudkan konsistensi data dan informasi terkait dengan bidang kelautan dan perikanan itu sendiri. Kemudian diplomasi diperlukan untuk mewujudkan terbentuknya kemauan untuk sharing data dan informasi antarnegara yang terkait. Implikasi kebijakan juga dapat terlihat pada saat melakukan kegiatan pertemuan dengan negara lain; karena ketegasan Indonesia dalam penanganan perikanan ilegal akan dapat menjadi salah satu bentuk peningkatan posisi tawar Indonesia pada saat Indonesia melakukan negosiasi dengan negara lain yang telah merugikan negara Indonesia. Sikap Indonesia yang serius menangani perikanan ilegal ini, akan membuat negara lain yang berminat untuk melakukan eksploitasi sumber daya ikan di Indonesia, akan melakukan hal tersebut secara legal dengan mematuhi aturan-aturan yang telah ditetapkan oleh pemerintah Indonesia. Diplomasi bidang kelautan dan perikanan yang kuat akan dapat mempermudah advokasi pada nelayan Indonesia yang melakukan pelanggaran di negara lain.

\section{DAFTAR PUSTAKA}

Departemen Pendidikan Nasional. 2008. Kamus Bahasa Indonesia (KBBI). Jakarta: Pusat Bahasa Departemen Pendidikan Nasional.

Dunn, W.N. 2001. Analisis Kebijaksanaan Publik. Penyadur: Dr. Muhadjir Darwin. Editor: Ari Wulandari, S.S. Yogyakarta: Hanindita Graha Widia, 2001. Judul asli: Public Policy Analysis; an introduction. $166 \mathrm{hlm}$.
Hornby, A.S. 2003. Advanced Oxford Dictionary. New York: Oxford University Press.

Investor Daily Indonesia. 2011. "RI Mendesak Miliki UU Kelautan”. Tgl. 7 Desember 2011 Hal. 7.

Kementerian Kelautan dan Perikanan. 2013. Kerjasama Antarlembaga. http://puskita.kkp. go.id/i2/index.php/kerjasama/kerjasama-antarlembaga/23-kerjasama.

Kementerian Luar Negeri. 2010. Keputusan Direktur Jenderal Multilateral Kementerian Luar Negeri (Kemenlu), Nomor 00148/PL/ II/2010/46/06 tentang Penetapan Rencana Strategis Direktorat Jenderal Multilateral Tahun 2010-2014. Jakarta : Kementerian Luar Negeri RI.

Koeshendrajana, S., Y. Dewita Sari., Tajerin, B.V.I. Yanti, F. Y. Arthatiani., Akhmad S., Bono B., Abdul S., Putri K. 2012. Laporan Akhir Kegiatan Kajian Hukum dalam Rangka Memerangi Kegiatan IUU Fishing di Indonesia. Jakarta: BBPSEKP, 2012. Unpublished.

Panikkar, K.M. 1956. The Principles of Diplomacy. Asia Publishing House.

Satow. 2009. Satow's Diplomatic Practice. Editor: Sir Ivor Roberts. New York: Oxford University Press.

Tulip, A., Nasriana, A. Idris. 2009. Kerjasama Indonesia dengan Negara-negara Tetangga Dalam Pemberantasan Kejahatan Transnasional. Laporan Penelitian Hibah Kompetitif Fakultas Hukum Universitas Sriwijaya. Palembang.

United Nations Office On Drugs And Crime. 2004. United Nations Convention Against Transnational Organized Crime And The Protocols Thereto. New York: United States.

Wahyuni, S. 2011. Qualitative Research Method Theory and Practice. Jakarta: Salemba Empat. 